\title{
Glutamine oxidation and utilization by rat and human oesophagus and duodenum
}

\author{
L. A. James ${ }^{1}$, P. G. Lunn ${ }^{1}$, S. Middleton ${ }^{2}$ and M. Elia ${ }^{1} *$ \\ ${ }^{1}$ MRC Dunn Clinical Nutrition Centre, Hills Road, Cambridge CB2 2DH, UK \\ ${ }^{2}$ Department of Gastroenterology, Addenbrooke's Hospital, Hills Road, Cambridge CB2 2QQ, UK
}

(Received 14 April 1998 - Revised 5 October 1998 - Accepted 20 November 1998)

\begin{abstract}
The rates of utilization and oxidation of glutamine and glucose by oesophageal and duodenal tissues have been investigated in both rats and human subjects. In the rat, glutamine utilization by oesophageal tissue was 2-3-fold lower than that in the duodenum, and this substrate contributed less than $10 \%$ to the total oxidative metabolism of the tissue, even when glutamine was the only substrate provided. In contrast, rat duodenal tissue derived about $34 \%$ of the total $\mathrm{CO}_{2}$ production from glutamine- $\mathrm{C}$, and this contribution was not suppressed by the addition of either glucose or a mixture of the other substrates. Rates of glucose utilization and oxidation by the duodenum were lower than those for glutamine, and were significantly $(P<0 \cdot 001)$ suppressed by addition of glutamine. In both oesophageal and duodenal tissues, less than $10 \%$ of the glutamine-C utilized was fully oxidized, approximately 60-70\% was converted to glutamate, and $30-40 \%$ to alanine. Results obtained using human biopsy tissue samples were similar to those observed in the rat. Glutamine oxidation contributed 34 (SD 4) \% of the total $\mathrm{CO}_{2}$ production by the duodenal tissue, but only 8 (SD 4$) \%$ to oesophageal tissue oxidation. The findings suggest that glutamine is not an important or preferred fuel for oesophageal tissue, whereas it is for duodenal tissue. Thus, these tissues can be expected to respond differently to glutamine administration.
\end{abstract}

Glutamine: Glutaminase: Glucose: Oesophagus: Duodenum

The amino acid glutamine is considered to be one of the most important fuels for the gastrointestinal tract (GIT; Windmueller \& Spaeth, 1978; Souba et al. 1990) and has been used to treat inflammatory conditions of the GIT, including upper GIT mucositis, which follows aggressive chemotherapy or radiotherapy (Elia, 1996; Elia \& Lunn, 1997). Similarly, short-chain fatty acids are considered to be important fuels for the colonic mucosa (Roediger, 1980; Ireland \& Jewell, 1980; Chapman et al. 1994) and have been used to treat colitis (Scheppach et al. 1992; Senagore et al. 1992; Elia, 1996). Metabolic fuels are important for maintaining cellular turnover and function of the GIT, but information about fuel selection by the human GIT in vivo is limited (Elia, 1996). This is partly due to the inaccessibility of the vessels draining the gut, and partly to uncertainty about the tissues involved in the exchange. For example, although the most consistent finding of arterioportal venous cannulation studies in human subjects is the net uptake of glutamine, it is not possible to assess the extent to which different tissues, or different parts of the same tissue (e.g. mucosal or non-mucosal layers of the GIT), are involved in the exchange because a variety of tissues drain into the portal vein (stomach, small and large intestine, and portal-drained viscera). Furthermore, arterio-portal cannulation studies provide no information about the metabolism of the upper GIT, which is drained by different vessels.

Many in vitro studies (Neptune, 1965; Watford et al. 1979; Roediger, 1980, 1982; Ardawi \& Newsholme, 1985; Ardawi, 1988; Firmansyah et al. 1989; Ireland \& Jewell, 1990; Fleming et al. 1991; Finnie et al. 1993; Kight \& Fleming, 1993; Chapman et al. 1994; Clausen \& Mortensen, 1994; Marsman \& McBurney, 1995; Okine et al. 1995; Wu et al. 1995) have attempted to overcome some of the difficulties associated with in vivo studies, but there is still a surprising lack of information about the metabolism of the GIT. For example, none of the previously mentioned studies have assessed the contribution of $\mathrm{CO}_{2}$ derived from glutamine to total $\mathrm{CO}_{2}$ production. Using enterocytes derived from the piglet, Darcy-Vrillon et al. (1994) measured the proportion of glutamine that was channelled towards oxidative metabolism. This measurement was repeated by $\mathrm{Wu}$ et al. (1995), who also found that $5 \mathrm{~mm}$-glucose did not reduce glutamine oxidation in enterocytes from neonatal pigs. In contrast, Okine et al. (1995) showed that glutamine 
oxidation by enterocytes from dairy cattle was reduced in the presence of glucose, but that $\mathrm{CO}_{2}$ production from glucose was likewise reduced in the presence of glutamine. Two studies measured oxidation of C-labelled glutamine by intestinal human mucosa (Finnie et al. 1993; Chapman et al. 1994), but did not assess the contribution of glutamine to total oxidative metabolism, the proportion of glutamine channelled towards oxidation, or the effect of other substrates on glutamine oxidation. Surprisingly, no study appears to have assessed the metabolism of glutamine in tissue derived from the oesophagus or mouth (rat or human).

We have attempted to obtain more comprehensive information about glutamine metabolism of the GIT in two ways: by measuring the activities of enzymes involved in glutamine metabolism throughout the GIT of human subjects and rats (James et al. 1998a,b) and by measuring the extent to which labelled and unlabelled substrates are utilized and contribute to oxidative metabolism. In the present paper we report on substrate energy metabolism of the oesophageal (with stratified squamous epithelium) and duodenal tissue (with columnar epithelium) and attempt to relate the findings to our published studies on enzyme activities (James et al. 1998a,b). The potential value of using glutamine as an oxidative fuel to treat disorders of the GIT is discussed with reference to these studies.

\section{Methods}

\section{Rats}

Individually-housed male rats, from the Dunn Nutrition Centre's colony of hooded rats, were maintained on a standard laboratory diet at $22^{\circ}$ with a $12 \mathrm{~h}$ light-dark cycle and free access to food and water. They were fed on standard rat chow pellets (Mix LAD1; Special Diet Service, Witham, Essex, UK), which contained (g/kg) approximately 100 carbohydrate, 200 protein and 40 fat. Rats were used in the study when they were $40-47 \mathrm{~d}$ of age and weighed $150-$ $200 \mathrm{~g}$. Food was not restricted before use.

\section{Tissue preparation}

Animals were killed by cervical dislocation, and the oesophagus or upper small intestine rapidly removed into icecold saline $(9 \mathrm{~g} \mathrm{NaCl} / \mathrm{l})$. The sections were flushed with ice-cold saline, slit lengthways and, using a scalpel, cut into approximately 30-40 mg slices. For the small intestine, a slice was obtained immediately before the junction with the jejunum. Tissues were weighed then divided further into approximately four pieces and used for metabolic experiments. Investigations using labelled glutamine preceded those with labelled glucose, and studies using duodenal tissue preceded that with the oesophagus.

\section{Patients}

Small biopsy specimens with wet weights ranging between 3.4 and $10.5 \mathrm{mg}$ were obtained from the oesophagus and duodenum of patients undergoing endoscopic examination. The patients were aged between 49 and 63 years of age and had no structural gastrointestinal abnormalities either endoscopically or histologically. They were diagnosed as having non-ulcer dyspepsia. None of the subjects were taking steroids, non-steroidal anti-inflammatory drugs, $\mathrm{H}_{2^{-}}$ receptor antagonists, or Ca-channel blockers such as omeprazole. Tissue biopsy samples were immediately weighed and placed in ice-cold pregassed $\left(\mathrm{O}_{2}\right.$ saturation $\left.400 \mathrm{ml} / \mathrm{l}\right) \mathrm{Krebs}-$ Henseleit buffer and transported within $5 \mathrm{~min}$ to the laboratory. Samples were incubated in Krebs-Henseleit buffer $\left(\mathrm{O}_{2}\right.$ saturation $400 \mathrm{ml} / \mathrm{l}$ ) containing $2 \mathrm{mM}-\mathrm{L}-\left[\mathrm{U}-{ }^{14} \mathrm{C}\right]$ glutamine (Wu et al. 1995).

The study was approved by the Local Research Ethics Committee, Addenbrooke's Hospital NHS Trust, and informed consent was obtained from all subjects before obtaining samples.

\section{Measurement of tissue oxygen consumption}

$\mathrm{O}_{2}$ consumption was measured polarographically by means of a Clark-type $\mathrm{O}_{2}$ electrode (Rank Brothers, Cambridge, UK). All measurements were carried out at $37^{\circ}$. The $\mathrm{O}_{2}$ electrode was calibrated with Krebs-Henseleit buffer $\left(\mathrm{O}_{2}\right.$ and $\mathrm{N}_{2}$ saturation 400 and $600 \mathrm{ml} / 1$ respectively). Background loss of $\mathrm{O}_{2}$ from the incubating medium lacking tissue was subtracted from values obtained in the presence of tissue. Rate of $\mathrm{O}_{2}$ uptake was expressed in $\mu \mathrm{mol} / \mathrm{min}$ per $\mathrm{g}$ wet weight. Preliminary experiments using duodenal and oesophageal tissues from rats weighing $10-40 \mathrm{mg}$ gave linear rates of $\mathrm{O}_{2}$ consumption for up to $30 \mathrm{~min}$. Similarly, human tissues weighing approximately $5-10 \mathrm{mg}$ gave linear rates for up to $45 \mathrm{~min}$, suggesting good tissue viability.

As only two $\mathrm{O}_{2}$ electrode cells were available, only two sets of incubation conditions could be assessed on each tissue preparation. To overcome possible statistical problems raised by this constraint, the sequence of incubation conditions used was randomly generated.

\section{Nutrient utilization}

In the rat, duodenal and oesophageal metabolism was assessed in the presence of either $2 \mathrm{mM}-\mathrm{L}-\left[\mathrm{U}-{ }^{14} \mathrm{C}\right]$ glutamine or $4 \mathrm{mM}-\mathrm{D}-$ $\left[\mathrm{U}-{ }^{14} \mathrm{C}\right]$ glucose. In studies involving competition between fuels, the final concentrations of the unlabelled substrates in the incubating medium were also $2 \mathrm{mM}$ and $4 \mathrm{mM}$ for glutamine and glucose respectively. In the final experiment, $4 \mathrm{mM}$-glucose, $2 \mathrm{mM}$-DL-3-hydroxybutyrate, $1 \mathrm{mM}$ acetoacetate, $1 \mathrm{~mm}$-lactate and $2 \mathrm{~mm}$-oleate were all added to the assay mixture containing radiolabelled glutamine. In the human study, biopsy samples were incubated in the presence of $2 \mathrm{mM}-\mathrm{L}-\left[\mathrm{U}-{ }^{14} \mathrm{C}\right]$ glutamine only. Oxidation of these substrates to $\mathrm{CO}_{2}$ over a $30 \mathrm{~min}$ incubation period was measured in conjunction with $\mathrm{O}_{2}$ consumption for that tissue.

Tissue samples were placed in the incubation chamber containing the $\mathrm{O}_{2}$ electrode and either $1.5 \mathrm{ml}$ or $2.0 \mathrm{ml}$ incubating medium depending on whether the added labelled substrate was glucose $(1.5 \mathrm{ml})$ or glutamine $(2.0 \mathrm{ml})$. The chamber was sealed with the perspex disc. Following incubation, approximately $1 \mathrm{ml}$ sample was withdrawn from the chamber via the small hole in the perspex disc by means of a preweighed syringe. The syringe and its contents were then reweighed. 5-Sulphosalicylic acid $(200 \mathrm{~g} / \mathrm{l} ; 100 \mu \mathrm{l})$ solution was added to the remaining incubation sample to terminate the reaction and this sample was used for the determination of metabolites. Samples were stored at $-80^{\circ}$ until analysis. 
To trace the conversion of substrates to $\mathrm{CO}_{2}$, a glass MacCartney bottle was used as the $\mathrm{CO}_{2}$ trapping system. 5Sulphosalicylic acid solution $(100 \mathrm{~g} / \mathrm{l} ; 0 \cdot 2 \mathrm{ml})$ was placed in an LP3 tube (Luckham, Life Sciences International, Basingstoke, Hants., UK) and inserted into the bottle. The bottle was sealed with a gas-tight rubber seal after the air had been displaced by gassing with $\mathrm{N}_{2}$ for $1 \mathrm{~min}$. $\mathrm{NaOH}(1.5 \mathrm{mM}$; $1 \mathrm{ml}$ ) with phenolphthalein indicator was injected through the rubber stopper into the bottle around the LP3 tube. Incubated sample was then injected through the rubber stopper into the LP3 tube, and the bottle was left on a rotating table overnight, so that the $\mathrm{NaOH}$ could absorb the $\mathrm{CO}_{2}$ liberated from the sample.

Trapped radioactivity (using $0.4 \mathrm{ml} 1.5 \mathrm{mM}-\mathrm{NaOH}$ ) was determined by liquid scintillation counting using $7.5 \mathrm{ml}$ Hionic-Fluor (Packard Instruments, Pangbourne, Berks., UK) plus $1.5 \mathrm{ml}$ hyamine hydroxide $(1 \mathrm{M})$, and a Packard Tri-Carb Minaxi liquid scintillation spectrometer (4000 series; Packard Instruments). Background radioactivity was determined using incubating medium lacking a tissue sample, and these values were subtracted from those obtained in the presence of tissue in each case. Preliminary studies had shown that recovery of $\mathrm{CO}_{2}$ by the trapping system was 99 (SD 3) \%. The remaining $\mathrm{NaOH}$ was titrated against $2 \mathrm{mM}-\mathrm{HCl}$ to determine total $\mathrm{CO}_{2}$ trapped by the $\mathrm{NaOH}$. Blanks representing $\mathrm{CO}_{2}$ present in the incubating medium without tissue was subtracted from those in the presence of tissue in each case. Preliminary measurements confirmed that $\mathrm{CO}_{2}$ production by both duodenal and oesophageal tissue occurred at a constant rate for at least $30 \mathrm{~min}$.

\section{Calculations}

The amount of $\mathrm{CO}_{2}$ (mol) derived from labelled substrate was calculated as:

$$
\mathrm{DPM} \text { (counted) } \times \frac{\mathrm{NaOH}(\text { total })}{\mathrm{NaOH}(\text { sample })} \times \frac{\text { Inc (total) }}{\text { Inc (sample) }}
$$$$
\times \text { specific activity of substrate } \times n \text {, }
$$

where DPM(counted) is the trapped radioactivity,
$\mathrm{NaOH}$ (total) is the volume of $\mathrm{NaOH}$ placed in the trapping system, $\mathrm{NaOH}$ (sample) is the volume of $\mathrm{NaOH}$ counted, Inc (total) is the total incubation volume, Inc (sample) is the volume removed for the $\mathrm{CO}_{2}$ estimations and $n$ is the no. of $\mathrm{C}$ atoms in the substrate. In the results, the amount of $\mathrm{CO}_{2}$ derived from labelled substrate is expressed as a percentage of total $\mathrm{CO}_{2}$ produced, calculated as follows.

Total $\mathrm{CO}_{2}$ produced (mol) was calculated from the titration data:

$$
\begin{aligned}
& (0 \text { - time acid volume }-30 \text { min acid volume }) \\
& \times \text { acid molarity } \times \frac{\mathrm{NaOH}(\text { total })}{\mathrm{NaOH}(\text { sample })} \times \frac{\text { Inc }(\text { total })}{\text { Inc }(\text { sample })},
\end{aligned}
$$

where acid volumes were the volumes of $\mathrm{HCl}$ added to neutralize the $\mathrm{NaOH}$ sample before and after incubation, $\mathrm{NaOH}$ (total) was the volume of $\mathrm{NaOH}$ placed in the trapping system, $\mathrm{NaOH}$ (sample) was the volume of $\mathrm{NaOH}$ titrated, Inc (total) and Inc (sample) were as described previously.

\section{Assays of metabolites}

Metabolites, (glutamine, glutamate, glucose, lactate and alanine) were determined spectrophotometrically using the Cobas Fara II centrifugal analyser (Roche, Welwyn Garden City, Herts., UK) in unneutralized 5-sulphosalicylic acid extracts of medium plus tissue, by enzymic methods involving changes in the extinction of $\mathrm{NAD}^{+}-\mathrm{NADH}$ at $355 \mathrm{~nm}$ (Khan et al. 1991). Glucose was measured using the Roche Unimates 5 GlucHK Assay Kit (Roche Diagnostic Systems, Welwyn Garden City, Herts., UK).

\section{Statistical analysis}

All results are expressed as means and standard deviations. Comparisons between values were made by ANOVA or Student's $t$ test using GraphPAD Instat software (GraphPAD Software, San Diego, CA, USA).

\begin{tabular}{|c|c|c|c|c|c|c|c|c|c|}
\hline \multirow[b]{2}{*}{ Additions to incubation } & \multicolumn{3}{|c|}{$\begin{array}{c}\mathrm{O}_{2} \text { uptake } \\
\text { ( } \mu \mathrm{mol} / \mathrm{min} \text { per } \\
\text { g wet wt) }\end{array}$} & \multicolumn{3}{|c|}{$\begin{array}{c}\mathrm{CO}_{2} \text { production } \\
(\mu \mathrm{mol} / \mathrm{min} \text { per } \\
\text { g wet wt })\end{array}$} & \multicolumn{3}{|c|}{$\begin{array}{l}\mathrm{CO}_{2} \text { derived from } \\
\text { oxidation of labelled } \\
\text { substrate }(\%)\end{array}$} \\
\hline & Mean & SD & $n$ & Mean & SD & $n$ & Mean & SD & $n$ \\
\hline $\begin{array}{l}\text { None } \\
{\left[\mathrm{U}-{ }^{14} \mathrm{C}\right] \text { glutamine }} \\
{\left[\mathrm{U}-{ }^{14} \mathrm{C}\right] \text { glutamine }+ \text { glucose }} \\
{\left[\mathrm{U}-{ }^{14} \mathrm{C}\right] \text { glutamine }+ \text { glucose }+ \text { lactate }+\mathrm{BOH}+\text { acetoacetate }+ \text { oleate }} \\
{\left[\mathrm{U}-{ }^{14} \mathrm{C}\right] \text { glucose }} \\
{\left[\mathrm{U}-{ }^{14} \mathrm{C}\right] \text { glucose }+ \text { glutamine }}\end{array}$ & $\begin{array}{l}-0 \cdot 98^{\mathrm{a}} \\
-1 \cdot 10^{\mathrm{a}} \\
-1.00^{\mathrm{a}} \\
-1.46^{\mathrm{b} * * *} \\
-1.05^{\mathrm{a}} \\
-1.05^{\mathrm{a}}\end{array}$ & $\begin{array}{l}0 \cdot 10 \\
0 \cdot 14 \\
0 \cdot 15 \\
0 \cdot 24 \\
0.22 \\
0 \cdot 17\end{array}$ & $\begin{array}{l}6 \\
6 \\
6 \\
6 \\
6 \\
5\end{array}$ & $\begin{array}{l}0.38^{\mathrm{a}} \\
0.62^{\mathrm{b*}} \\
0.51^{\mathrm{ab}} \\
0.59^{\mathrm{b*}} \\
0.31^{\mathrm{a}} \\
0.41^{\mathrm{a}}\end{array}$ & $\begin{array}{l}0.18 \\
0.12 \\
0.16 \\
0.14 \\
0.11 \\
0.07\end{array}$ & $\begin{array}{l}5 \\
5 \\
6 \\
6 \\
5 \\
5\end{array}$ & $\begin{array}{l}- \\
34 \cdot 0^{\mathrm{a}} \\
38 \cdot 1^{\mathrm{a}} \\
36 \cdot 1^{\mathrm{a}} \\
22 \cdot 8^{\mathrm{b}}+\dagger \\
7 \cdot 3^{\mathrm{c}} \text { †††㧊 }\end{array}$ & $\begin{array}{l}- \\
4 \cdot 3 \\
6 \cdot 4 \\
6 \cdot 8 \\
5 \cdot 4 \\
1 \cdot 8\end{array}$ & $\begin{array}{l}5 \\
6\end{array}$ \\
\hline
\end{tabular}

Table 1. Oxidative changes following addition of substrates to rat duodenal tissue§l\|

(Mean values and standard deviations for no. of separate experiments indicated)

$\mathrm{BOH}, 3$-hydroxybutyrate.

a,b,c Mean values within a column with unlike superscript letters were significantly different (ANOVA; $P<0.05$ ).

Mean values were significantly different from those for the control incubation (no additions; ANOVA): ${ }^{*} P<0.05,{ }^{* * *} P<0.001$.

Mean values were significantly different from those for glutamine only (ANOVA): †† $P<0.01$, $† \dagger P<0.001$.

Mean values were significantly different from those for glucose only (ANOVA): $\neq \neq \ddagger P<0.001$.

$\S$ Positive values indicate production, negative values indicate utilization.

॥l For details of procedures, see pp. 324-325. 
Table 2. Oxidative changes following addition of substrates to rat oesophageal tissueł‡ (Mean values and standard deviations for no. of separate experiments indicated)

\begin{tabular}{|c|c|c|c|c|c|c|c|c|c|}
\hline \multirow[b]{2}{*}{ Additions to incubation } & \multicolumn{3}{|c|}{$\begin{array}{c}\mathrm{O}_{2} \text { uptake } \\
\text { ( } \mu \mathrm{mol} / \mathrm{min} \text { per } \\
\text { g wet wt })\end{array}$} & \multicolumn{3}{|c|}{$\begin{array}{c}\mathrm{CO}_{2} \text { production } \\
\text { ( } \mu \mathrm{mol} / \mathrm{min} \text { per } \\
\mathrm{g} \text { wet wt) }\end{array}$} & \multicolumn{3}{|c|}{$\begin{array}{l}\mathrm{CO}_{2} \text { derived from } \\
\text { oxidation of labelled } \\
\text { substrate }(\%)\end{array}$} \\
\hline & Mean & $S D$ & $n$ & Mean & SD & $n$ & Mean & SD & $n$ \\
\hline $\begin{array}{l}\text { None } \\
{\left[\mathrm{U}-{ }^{14} \mathrm{C}\right] \text { glutamine }} \\
{\left[\mathrm{U}-{ }^{14} \mathrm{C}\right] \text { glutamine }+ \text { glucose }} \\
{\left[\mathrm{U}-{ }^{14} \mathrm{C}\right] \text { glutamine + glucose }+ \text { lactate }+\mathrm{BOH}+\text { acetoacetate }+ \text { oleate }} \\
{\left[\mathrm{U}-{ }^{14} \mathrm{C}\right] \text { glucose }} \\
{\left[\mathrm{U}-{ }^{14} \mathrm{C}\right] \text { glucose + glutamine }}\end{array}$ & $\begin{array}{l}-0.69^{\mathrm{a}} \\
-0.65^{\mathrm{a}} \\
-0.82^{\mathrm{a}} \\
-0.72^{\mathrm{a}} \\
-0.83^{\mathrm{a}} \\
-0.78^{\mathrm{a}}\end{array}$ & $\begin{array}{l}0.16 \\
0.18 \\
0.16 \\
0.17 \\
0.16 \\
0.11\end{array}$ & $\begin{array}{l}5 \\
6 \\
6 \\
6 \\
6 \\
6\end{array}$ & $\begin{array}{l}0.32^{\mathrm{a}} \\
0.63^{\mathrm{b} *} \\
0.52^{\mathrm{ab}} \\
0.48^{\mathrm{ab}} \\
0.39^{\mathrm{ab}} \\
0.55^{\mathrm{ab}}\end{array}$ & $\begin{array}{l}0.18 \\
0.27 \\
0.17 \\
0.13 \\
0.17 \\
0.09\end{array}$ & $\begin{array}{l}6 \\
5 \\
6 \\
6 \\
5 \\
5\end{array}$ & $\begin{array}{c}- \\
7.9^{\mathrm{a}} \\
9.5^{\mathrm{a}} \\
7 \cdot 4^{\mathrm{a}} \\
10 \cdot 5^{\mathrm{a}} \\
8.6^{\mathrm{a}}\end{array}$ & $\begin{array}{l}- \\
3 \cdot 7 \\
2.1 \\
3.4 \\
3.0 \\
1.0\end{array}$ & $\begin{array}{l}5 \\
6\end{array}$ \\
\hline
\end{tabular}

$\mathrm{BOH}, 3$-hydroxybutyrate.

a,b Mean values within a column with unlike superscript letters were significantly different (ANOVA; $P<0.05)$.

Mean value was significantly different from that for the control incubation (no additions; one-way ANOVA): ${ }^{\star} P<0.05$

$\dagger$ Positive values indicate production, negative values indicate utilization.

$\ddagger$ For details of procedures, see pp. 324-325.

\section{Results}

\section{Rat studies}

Gaseous exchange. The rates of $\mathrm{O}_{2}$ uptake by duodenal tissue incubated with different substrates are shown in Table 1. Without added substrate, the uptake of $\mathrm{O}_{2}$ was $0.98 \mu \mathrm{mol} / \mathrm{min}$ per $\mathrm{g}$ tissue wet weight. Addition of the full mix of substrates (glutamine, glucose, lactate, ketone bodies and oleate) to the incubation medium significantly increased the rate of $\mathrm{O}_{2}$ uptake by this tissue $(P<0.001)$, but uptake was unaffected by the addition of glutamine or glucose alone, or in combination. $\mathrm{CO}_{2}$ production was $0.38 \mu \mathrm{mol} /$ min per $g$ wet weight in the absence of added substrates, and was significantly increased by the addition of glutamine or the full mix of substrates to the incubation medium $(P<$ $0 \cdot 05$ ). In contrast, addition of glucose did not increase $\mathrm{CO}_{2}$ production above baseline (Table 1).

A substantial percentage (34) of total $\mathrm{CO}_{2}$ production by duodenal tissue was derived from the oxidation of glutamine, and this contribution to $\mathrm{CO}_{2}$ production was not reduced in the presence of either glucose, or a mixture of glucose, lactate, ketone bodies and oleate. In contrast, the percentage of $\mathrm{CO}_{2}$ derived from the oxidation of glucose (i.e. with glucose only in the medium) was lower than that for glutamine (i.e. glutamine only in the medium; $23 \% v$. $34 \% ; P<0.01)$ and this was suppressed by approximately $70 \% \quad(P<0.001)$ when glutamine was added to the incubation medium.

With oesophageal tissue (Table 2) $\mathrm{O}_{2}$ uptake in the absence of added substrate was significantly lower than that for the duodenum $(P<0.01)$ and did not increase with substrate addition. Basal $\mathrm{CO}_{2}$ production was similar to that seen with duodenal tissue and only increased significantly when glutamine was added $(P<0.05)$. The percentage of $\mathrm{CO}_{2}$ derived from the oxidation of glutamine by oesophageal tissue was 4-5-fold lower than the value for the duodenum $(34 \%$ v. $8 \% ; P<0.001)$ but as with the duodenal data, this percentage was not reduced in the presence of glucose or the full substrate mix (Tables 1 and 2). With the oesophageal tissue, the percentage of $\mathrm{CO}_{2}$ derived from the oxidation of glucose was similar to that from glutamine, $(11 \% v .8 \%)$ and was not suppressed by addition of glutamine. The contribution of glucose oxidation to $\mathrm{CO}_{2}$ production was higher in the duodenum than the oesophagus (23 (SD 5) \% v. 11 (SD 3) \%; $P<0.001$; Tables 1 and 2).

Substrate utilization and metabolite production. The rate of glutamine utilization by duodenal tissue was $0.49 \mu \mathrm{mol} / \mathrm{min}$ per $\mathrm{g}$ wet weight compared with only

Table 3. Changes in metabolite concentration in rat duodenal tissue following 30 min incubation* $†$ (Mean values and standard deviations for no. of separate experiments indicated)

\begin{tabular}{|c|c|c|c|c|c|c|c|c|c|c|c|}
\hline \multirow[b]{2}{*}{ Additions to incubation } & \multirow[b]{2}{*}{$n$} & \multicolumn{10}{|c|}{ Rates of utilization or production ( $\mu \mathrm{mol} / \mathrm{min}$ per g wet wt) } \\
\hline & & Mean & SD & Mean & SD & Mean & SD & Mean & SD & Mean & SD \\
\hline None & 6 & - & - & - & - & $0.04^{\mathrm{a}}$ & 0.04 & $0.24^{a}$ & 0.08 & $0.09^{a}$ & 0.03 \\
\hline Glutamine & 6 & $-0.49^{a}$ & 0.09 & - & - & $0.31^{\mathrm{b}}$ & 0.06 & $0.33^{a}$ & 0.07 & $0.17^{\mathrm{bc}}$ & 0.02 \\
\hline Glutamine + glucose & 11 & $-0.51^{\mathrm{a}}$ & 0.13 & $-0.68^{a}$ & 0.53 & $0.34^{\mathrm{b}}$ & 0.07 & $1.42^{b}$ & 0.32 & $0.20^{\mathrm{C}}$ & 0.04 \\
\hline Glutamine + glucose + lactate $+\mathrm{BOH}+$ acetoacetate + oleate & 6 & $-0 \cdot 70^{b}$ & 0.09 & $-1 \cdot 12^{\mathrm{a}}$ & 0.21 & $0.43^{\mathrm{c}}$ & 0.03 & - & - & $0 \cdot 15^{b}$ & 0.03 \\
\hline
\end{tabular}

$\mathrm{BOH}, 3$-hydroxybutyrate.

a,b,c Mean values within a column with unlike superscript letters were significantly different (ANOVA; $P<0.05)$.

* Positive values indicate metabolite production, negative values indicate substrate utilization.

†For details of procedures, see pp. 324-325. 
$0.14 \mu \mathrm{mol} / \mathrm{min}$ per $\mathrm{g}$ wet weight for the oesophageal tissue $(P<0.001$; Tables 3 and 4$)$. This was not reduced by the presence of glucose in either tissue. Addition of glucose, lactate, ketone bodies and oleate to the incubation medium resulted in a significant increase $(P<0.05)$ in glutamine utilization in both the oesophagus and duodenum. Most of the glutamine utilized by the duodenum was converted to glutamate $(60-70 \%)$, and alanine (30-40\%; Tables 3 and 4). Less than $10 \%$ of the utilized glutamine-C was oxidized (9 (SD 2) \% by the duodenum and 7 (SD 3) \% by the oesophagus). These values were unaffected by the presence of glucose in the incubation, but glutamate (although not alanine) production was significantly increased when all substrates were present $(P<0 \cdot 05$; Table 3$)$. Glutamate and alanine production by oesophageal tissue incubated with glutamine were very low and not significantly greater than amounts produced in the absence of substrate (Table 4).

Both duodenal and oesophageal tissues utilized glucose at similar rates $(0.82$ and $0.73 \mu \mathrm{mol} / \mathrm{min}$ per $\mathrm{g}$ wet weight respectively; Tables 3 and 4), and this was not decreased in the presence of glutamine. Incubation of both tissues with glucose resulted in significant increases in lactate production $(P<0.05)$ and small increments in glutamate and alanine above the endogenous production rates (Tables 3 and 4). Lactate was the major metabolite produced, accounting for 68 and $40 \%$ of the glucose utilized by duodenal and oesophageal tissues respectively, when glucose was the only substrate (assuming two mol lactate are produced per mol glucose; Tables 3 and 4). In both tissues less than $2 \%$ of the glucose utilized was fully oxidized (1.3 (SD 0.4) \% by the duodenum and 1.5 (SD 0.7$) \%$ by the oesophagus).

\section{Human study}

The rates of $\mathrm{O}_{2}$ uptake by duodenal and oesophageal tissues in the presence of glutamine were significantly different $(P<0.05 ; 1.26$ and $0.85 \mu \mathrm{mol} / \mathrm{min}$ per $\mathrm{g}$ wet weight respectively; Table 5). $\mathrm{CO}_{2}$ production tended to be higher in the duodenum than in the oesophagus, but because of a rather high variance the difference did not reach statistical significance. However, the percentage of $\mathrm{CO}_{2}$ derived from the oxidation of glutamine was 4-5-fold higher in the duodenum than the oesophagus $(P<0.001)$. Overall, the findings from the human study were very similar to observations made with the rat tissues (Tables 1 and 2).

\section{Discussion}

This is the first study to demonstrate that the oesophagus utilizes very little glutamine compared with the duodenum. It also shows that glutamine contributes little to the oxidative metabolism of this tissue $(<10 \%$ in both rat and human subjects), even when glutamine is the only added substrate in the incubation medium. Our conclusion that glutamine is not a preferred fuel for the oesophagus is consistent with the low activity of glutaminase (EC 3.5.1.2) in both rat and human oesophageal tissue (James et al. 1998a,b). Indeed, glutaminase activity here is weaker than in any other part of the GIT.

In contrast to oesophageal tissue, the small intestine appears to use glutamine as a preferred substrate. The 
Table 5. Oxidative metabolism of human oesophageal and duodenal mucosal biopsies in the presence of $2 \mathrm{mM}-\mathrm{L}-\left[\mathrm{U}-{ }^{\uparrow} \mathrm{C}\right] \mathrm{glutamine} † \ddagger$

(Mean values and standard deviations for no. of separate experiments shown)

\begin{tabular}{lccccccc}
\hline & \multicolumn{3}{c}{ Duodenum } & & \multicolumn{3}{c}{ Oesophagus } \\
\cline { 2 - 3 } & Mean & SD & $n$ & & Mean & SD & $n$ \\
\hline $\begin{array}{c}\mathrm{O}_{2} \text { uptake } \\
(\mu \mathrm{mol} / \text { min per g wet wt })\end{array}$ & -1.26 & $0.28^{*}$ & 6 & & -0.85 & 0.17 & 6 \\
$\begin{array}{c}\mathrm{CO}_{2} \text { production } \\
(\mu \mathrm{mol} / \text { min per g wet wt })\end{array}$ & 1.04 & 0.26 & 6 & & 0.77 & 0.26 & 5 \\
$\begin{array}{c}\mathrm{CO}_{2} \text { derived from } \\
\text { oxidation of glutamine }\end{array}$ & 34 & $3^{* * *}$ & 5 & 7 & 3 & 5 \\
\hline
\end{tabular}

Mean values were significantly different from those for the oesophagus (Student's $t$ test): ${ }^{*} P<0.05$; ${ }^{* * *} P<0.001$.

†Positive values indicate $\mathrm{CO}_{2}$ production, negative values indicate $\mathrm{O}_{2}$ utilization.

$\ddagger$ For details of procedures, see pp. 324-325.

duodenum rapidly utilizes glutamine, which contributes approximately $35 \%$ of the $\mathrm{CO}_{2}$ produced. This high rate of utilization is again consistent with our finding of high glutaminase activity in the small intestine (James et al. $1998 a, b)$. In addition, the high rates of glutamine utilization and oxidation are not suppressed in the presence of glucose or a mixture of substrates that include glucose. In contrast, glucose oxidation is readily suppressed by glutamine (Table 1). This preferential oxidation of glutamine rather than glucose was also observed by Wu et al. (1995) working with enterocytes from neonatal pigs. In contrast, enterocytes from lactating cows showed a preference for glucose rather than glutamine (Okine et al. 1995). Such studies support the view that glutamine is the preferred oxidative fuel for the mucosa of the small intestine of single-stomached animals, but that the situation in ruminants may be different (Okine et al. 1995).

The rate of $\mathrm{O}_{2}$ consumption by the duodenal mucosa is slightly lower than that reported for human enterocytes (Ashy et al. 1988). The study of Finnie et al. (1993) reported on glutamine oxidation by human mucosal biopsies of the small intestine (although not of the oesophagus), but did not measure the rate of $\mathrm{O}_{2}$ or $\mathrm{CO}_{2}$ production. Thus, the contribution of glutamine to overall oxidative metabolism could not be assessed. Our studies suggest that less than $10 \%$ of the glutamine utilized by the rat tissue is used for oxidation (consistent with results of the pig enterocytes; Darcy-Vrillon et al. 1994; Wu et al. 1995). The majority is converted to glutamate and alanine. However, the amount of glutamine metabolized by the duodenal slices (i.e. $0 \cdot 50 \mu \mathrm{mol} / \mathrm{min}$ per $\mathrm{g}$ wet weight) is far less than the potential amount which could be utilized given the substantial in vitro measured activity of glutaminase present in this tissue (i.e. $17 \cdot 2 \mu \mathrm{mol} / \mathrm{min}$ per g wet weight; James et al. $1998 a$ ). This 35 -fold difference is similar to the previously reported 30-40-fold difference between total GIT glutaminase activity and glutamine uptake measured by arteriovenous difference (James et al. 1998a,b). Thus, glutamine utilization measured by this tissue-slice technique gives values similar to those obtained by measuring in vivo glutamine uptake. There are several possible reasons for the discrepancy between glutaminase activity and tissue utilization of glutamine. First, the concentration of phosphate in vivo may not be as high as that necessary for full activation of the phosphate-dependent glutaminase (approximately $150 \mathrm{~mm}$; Pinkus \& Windmueller, 1977). Second, the presence of inhibitors in vivo, e.g. glutamate, will reduce the activity of glutaminase. Third, the activity of the enzyme is substrate dependent; the presence of non-saturable mucosal concentrations of glutamine will prevent full activity of glutaminase. (The Michaelis-Menten constants for rat and human small intestinal glutaminases are 2.7 and $3.8 \mathrm{mM}$-glutamine, compared with mucosal concentrations of 1.0 and $0.6 \mathrm{mM}$ glutamine respectively; James et al. 1998a,b). Fourth, the local $\mathrm{pH}$ and accessibility of substrate to the enzyme, which is in the mitochondria, could affect the rate of glutamine utilization.

The rates of oxidation of both glutamine and glucose by the oesophageal tissue were both low, indicating that $\mathrm{CO}_{2}$ production by this tissue was mainly from some endogenous substrate. Clearly, more studies are required to establish the preferential or major oxidative fuel for this tissue.

Glutamine has a number of potentially beneficial effects on the GIT (Elia, 1996), including the following: synthesis of nucleic acids, which are especially important for rapidlydividing cells such as the epithelial cells of the GIT mucosa; synthesis of amino sugars, which are present in mucus (part of the GIT barrier); increase in intestinal blood flow; and a source of energy. However, the finding in the present study that glutamine is not an important energy substrate for oesophageal tissue, could provide an explanation for the lack of effect of glutamine in treating mucositis of the upper GIT induced by chemotherapy or radiotherapy (Jebb et al. 1994, 1995). If the oxidation of glutamine is important in maintaining integrity of the GIT, it is likely to be of more value in treating conditions affecting the small intestine (Wischemeyer et al. 1993; Poynton et al. 1995; Elia \& Lunn, 1997) which preferentially utilizes glutamine as an energy source.

In conclusion, the present study demonstrates that oesophageal and duodenal tissues have different fuel preferences in both rat and human subjects. Whilst glutamine is a preferred substrate for the small intestine it is not for the oesophagus. This preference is consistent with the high glutaminase activity in the small intestine and low activity in the oesophagus. 


\section{References}

Ardawi MSM (1988) Glutamine and ketone body metabolism in the gut of streptozotocin-diabetic rats. Biochemistry Journal 249, 565-572.

Ardawi MSM \& Newsholme EA (1985) Fuel utilization in colonocytes of the rat. Biochemistry Journal 231, 713-719.

Ashy AA, Ardawi MSM \& Salleh M (1988) Glucose, glutamine and ketone-body metabolism in human enterocytes. Metabolism 37, 602-609.

Chapman MAS, Grahn MF, Boyle MF, Hutton M, Rogers J \& Williams NS (1994) Butyrate oxidation is impaired in the colonic mucosa of sufferers of quiescent ulcerative colitis. Gut 35, 73-76.

Clausen MR \& Mortensen PB (1994) Kinetic studies on the metabolism of short-chain fatty acid and glucose by isolated rat colonocytes. Gastroenterology 106, 423-432.

Darcy-Vrillon B, Posto L, Morel M-T, Bernard F, Blachier F, Meslin J-C \& Dueé P-H (1994) Glucose, galactose, and glutamine metabolism in pig isolated enterocytes during development. Pediatric Research 36, 175-181.

Elia M (1996) Metabolism and nutrition of the gastrointestinal tract. In Recent Developments in Infant Nutrition, pp. 318-348 [JG Bindels, AC Goedhart and HKA Visser, editors]. Boston, MA and London: Kluwer Academic Publishers.

Elia M \& Lunn PG (1997) The use of glutamine in the treatment of gastrointestinal disorders in man. Nutrition 13, 743-747.

Finnie IA, Taylor BA \& Rhodes JM (1993) Ileal and colonic epithelial metabolism in quiescent ulcerative colitis: increased glutamine metabolism in distal colon but no defect in butyrate metabolism. Gut 34, 1552-1558.

Firmansyah A, Penn D \& Lebenthal E (1989) Isolated colonocyte metabolism of glucose, glutamine, $n$-butyrate and $\beta$-hydroxybutyrate in malnutrition. Gastroenterology 97, 622-629.

Fleming SE, Fitch MD, DeVries S, Liu ML \& Kight C (1991) Nutrient utilization by cells isolated from rat jejunum, cecum and colon. Journal of Nutrition 121, 869-878.

Ireland A \& Jewell DP (1990) 5-aminosalicylic acid (5-ASA) has no effect on butyrate metabolism in human colonic epithelia cells. Gastroenterology 98, Suppl., A176.

James LA, Lunn PG \& Elia M (1998a) Glutamine metabolism in the rat assessed by the relative activities of glutaminase ( $E C$ 3.5.1.2) and glutamine synthetase (EC 6.3.1.2). British Journal of Nutrition 79, 365-372.

James LA, Lunn P, Middleton S \& Elia M (1998b) Distribution of glutaminase (EC 3.5.1.2) and glutamine synthetase (EC 6.3.1.2) activities in the human gastrointestinal tract. Clinical Science 94, 313-319.

Jebb SA, Marcus R \& Elia M (1995) A pilot study of oral glutamine supplementation in patients receiving bone marrow transplants. Clinical Nutrition 14, 162-165.

Jebb SA, Osborne RJ, Maughant TS, Mohideen N, Mack P, Mart D, Shelleg MD \& Elia M (1994) 5-Fluorouracil and folinic acid induced mucositis: no effect of oral glutamine supplementation. British Journal of Cancer 70, 732-735.
Khan K, Blaak E \& Elia M (1991) Quantifying intermediary metabolites after a single deproteinisation step with sulphosalicylic acid. Clinical Chemistry 37, 728-733.

Kight CE \& Fleming SE (1993) Nutrient oxidation by rat intestinal epithelial cells is concentration dependent. Journal of Nutrition 123, 876-882.

Marsman KE \& McBurney MI (1995) Dietary fibre increases oxidative metabolism in colonocytes but not in distal small intestine enterocytes isolated from rats. Journal of Nutrition 125, 273-282.

Neptune E (1965) Respiration and oxidation of various substrates by ileum in vitro. American Journal of Physiology 209, 329332.

Okine EK, Glimm DR, Thompson JR \& Kennelly JJ (1995) Influence of stage of lactation on glucose and glutamine metabolism in isolated enterocytes from dairy cattle. Metabolism 44, 325-331.

Pinkus LM \& Windmueller HG (1977) Phosphate dependent glutaminase of small intestine: Localisation and role in intestinal glutamine metabolism. Archives of Biochemistry and Biophysics 182, 506-517.

Poynton CH, Maughan TS, Jebb S \& Elia M (1995) Glycyl Lglutamine reduces gut toxicity in bone marrow transplantation. Blood 86, Suppl. 1, 2258.

Roediger WEW (1980) The colonic epithelium in ulcerative colitis: an energy deficiency disease? Lancet ii, 712-715.

Roediger WEW (1982) Utilization of nutrients by isolated epithelial cells of the rat colon. Gastroenterology 83, 424-429.

Scheppach W, Sommer H, Kirchner I, Paganelli G-M, Bartram P, Christl S, Richter F, Dusel G \& Kasper H (1992) Effect of butyrate enemas on the colonic mucosa in distal ulcerative colitis. Gastroenterology 103, 51-56.

Senagore AJ, MacKeigan JM, Schneider M \& Ebrom S (1992) Short-chain fatty acid enemas: a cost effective alternative in the treatment of non-specific proctosigmoiditis. Diseases of the Colon and Rectum 35, 923-927.

Souba WW, Klimberg S, Plumley DA, Sallom RM, Flynn TC, Bland KI \& Copeland EM (1990) The role of glutamine in maintaining a healthy gut and supporting the metabolic response to injury and infection. Journal of Surgical Research 48, 383-391.

Watford M, Lund P \& Krebs HA (1979) Isolation and metabolic characteristics of rat and chicken enterocytes. Biochemistry Journal 178, 589-596.

Windmueller HG \& Spaeth AE (1978) Identification of ketone bodies and glutamine as the major respiratory fuels in vivo for the postabsorptive rat small intestine. Journal of Biological Chemistry 253, 69-76.

Wischemeyer P, Pemberton JH \& Phillips SF (1993) Chronic pouchitis after ileal pouch anastomosis: responses to butyrate and glutamine suppositories in a pilot study. Mayo Clinical Proceedings 68, 978-981.

Wu G, Knabe DA, Yan W \& Flynn NE (1995) Glutamine and glucose metabolism in enterocytes of the neonatal pig. American Journal of Physiology 268, R334-R342. 